\title{
Effect of weeds management toward understorey species diversity and soil fertility under oil palm plantation
}

\author{
Miswarti $^{1 *}$, Andi Ishak $^{1}$, Wahyuni Amelia Wulandari ${ }^{1}$, Jhon Firison ${ }^{1}$, Siti Rosmanah ${ }^{1}$, \\ Erpan Ramon ${ }^{1}$, Nurmegawati ${ }^{1}$, Irma Calista $^{1}$, Yahumri ${ }^{1}$, Yudi Sastro $^{2}$ \\ ${ }^{1}$ Assessment Institute Agriculture Technology (AIAT) of Bengkulu, Jl. Irian km 6,5 Kota Bengkulu \\ (38119) \\ ${ }^{2}$ Indonesian Center for Rice Research (ICRR). Jl Raya .9, Tromol Pos 11, Cikampek Subang (41256)
}

\begin{abstract}
The objectives of this study was to determine soil fertility and types of plants in understorey ecosystems in oil palm plantation stand which are managed in different ways. The data collection method was a direct observation on smallholder oil palm plantation at 15 years of age with different management, namely: 1) weed control using herbicides, 2) without management, and 3 ) used for beef cattle grazing. The data consisted of soil fertility and identification of understorey species in each management. The soil samples were taken in a composite manner and analyzed in the laboratory, while the plant species samples were gathered using the $1 \times 1 \mathrm{~m}^{2}$ method and identified using an identification manual. From the results, weed control in oil palm plantation with cattle grazing has a positive impact on soil fertility compared to the use of herbicides and without control. The diversity of understorey species in cattle grazing locations is less, namely, as much as 11 species compared to the use of herbicides ( 15 species) and without control ( 22 species). Weed management by grazing cows in the oil palm plantation increased land fertility and the dominance of understorey plants as a source of animal feed.
\end{abstract}

\section{Introduction}

Oil palm is the dominant plantation commodity in Indonesia, the area of oil palm plantations reaches 14.33 million ha and $40.62 \%$ is smallholder plantation [1]. Oil palm began to be developed since the 1970s in Sumatera and Kalimantan [2]. Oil palm has become one of the leading plantation commodities in Bengkulu Province with an area of 208,627 hectares or $50.36 \%$ of the total plantation area [3]. The problems faced by farmers in the management of oil palm plantations are that they are not optimal and lack the handling of plant maintenance factors, including soil fertility and the management of undergrowth of oil palm plantation which causes low production.

Undergrowth under oil palm plantation is often considered a weed that is detrimental to farmers and needs to be controlled. Whereas understorey under oil palm plantation can be

* Corresponding author: misbachza@yahoo.co.id 
integrated with beef cattle with semi-intensive and extensive livestock rearing patterns [4]. These two commodities (palm and cattle) can be synergized so that the land is used optimally. To meet the needs of the growing and developing oil palm plants requires food intake in fertilizer derived from cows, while oil palm undergrowth can be used as cattle feed $[5,6]$.

Understorey management is carried out in various ways, such as being controlled with herbicides (considered as oil palm weeds), and without herbicides and beef cattle grazing, and used integrating with beef cattle grazing. Grazing beef cattle under oil palm plantation will be beneficial for oil palm plantations. Cattle that consume understorey can reduce weeding costs, reduce fertilization costs due to livestock manure (feces and urine) from grazing activity.

Lubuk Banyau Bengkulu village has three oil palm plantation management (controlled with herbicides, without herbicides and beef cattle grazing and integrated with beef cattle grazing. The grazing fields management will increase soil fertility and palm oil production. Therefore, the study aimed to determine the soil fertility and types of plants in understorey ecosystems in oil palm plantation managed in several ways.

\section{Materials and method}

The research was carried out in Lubuk Banyau Village, Padang Jaya District, North Bengkulu Regency, Bengkulu Province from April to May 2021. The location was chosen because North Bengkulu is an area that has a lot of oil palm planting and Lubuk Banyau is one of the smallholder oil palm plantations in Bengkulu Province. The method used in this study was the identification and direct observation of smallholder oil palm plantation around $>15$ years with different management, namely 1) weed control using herbicides, 2) 2) without using herbicides and beef cattle grazing, and 3)used for beef cattle grazing. The composite soil samples were analyzed in the soil laboratory with some chemical and physical parameters. Meanwhile, the sampling method of understorey was using the $1 \times 1$ meter square and identified using an identification guide book. In addition, interview questions with three landowners were conducted to get an overview of their management. The questions covered the weeds management and fields management. The data obtained were analyzed descriptively.

\section{Result and discussion}

\subsection{Management of the existing understorey of the oil palm plantation}

Lubuk Banyau Village is a lowland area located in the Padang Jaya sub-district, North Bengkulu Regency. The area of oil palm plantations in North Bengkulu is 11,887.5 ha [7] consisting of private plantations and smallholder plantations. The development of smallholder oil palm began around 2004 and the application of technology in the management of oil palm is still traditional. The management of oil palm is presented in Table 1.

Cattle rearing is carried out extensively, kept around oil palm plantation day and night, not caged but tethered or tied around the land. To meet the feed needs of Bali cattle, farmers do not provide concentrate but the feed is obtained from the grass around the oil palm plantation and every three days the cows are moved to a place where the plants have not been eaten. When farmers move cattle to the next place, livestock manure is taken and placed around the oil palm plantations. In addition, with cattle grazing in oil palm plantation, the 
land becomes clean due to being always eaten by cattle. [8] more cattle graze on their oil palm plantation own and few farmers provide additional food.

Table 1. Management of existing the understorey of the oil palm plantation in Lubuk Banyau

\begin{tabular}{|c|c|c|c|c|}
\hline \multirow[b]{2}{*}{ No. } & \multirow{2}{*}{$\begin{array}{l}\text { Technology } \\
\text { Components }\end{array}$} & \multicolumn{3}{|c|}{ Management of oil palm plantation understorey } \\
\hline & & Herbicides & $\begin{array}{l}\text { Without herbicides and } \\
\text { beef cattle grazing }\end{array}$ & Beef cattle grazing \\
\hline 1 & Palm age & 15 years & 15 years & 15 years \\
\hline 2 & Seed & Superior & Superior & Superior \\
\hline 3 & Planting distance & $9 \times 10 \mathrm{~m}$ & $9 \times 10 \mathrm{~m}$ & $9 \times 10 \mathrm{~m}$ \\
\hline 4 & Anorganic Fertilizer & Not available & Not available & Not available \\
\hline 5 & Weeding & Twice a year & Not available & Not available \\
\hline 6 & Cattle raising & Not available & Not available & Available (Bali Cattle) \\
\hline
\end{tabular}

Extensive cattle rearing is expected to sustain in Lubuk Banyau Village. Therefore, it is essential to know the carrying capacity of the understorey in oil palm plantation so that the government can plan a beef cattle development program in smallholder oil palm plantation to improve the welfare of farmers.

\subsection{Identification of soil fertility in understorey oil palm plantation}

Weed management in different oil palm plantation will affect soil fertility. Based on the results of soil analysis, the soil fertility of each plantation whose management used herbicides, without herbicides and Bali cattle grazing was found (Tab.1). Soil is one of the essential natural resources that needs serious attention to avoid damage that can reduce productivity. It can be seen that the soil texture in oil palm plantation with different weed management has different textures, namely clay, clay and dusty clay. Soil texture is the relative ratio between the fractions of sand, silt and clay. Soil particles whose effective diameter is $<2 \mathrm{~mm}$, which is closely related to the movement of water and solutes, air, heat movement, soil volume weight, specific surface area, ease compacted soil.

Table 2. Soil fertility conditions in oil palm plantation understorey between management using herbicides, non-herbicides and cattle rearing.

\begin{tabular}{|l|c|c|c|c|c|c|}
\hline \multirow{2}{*}{ Parameter } & \multicolumn{5}{|c|}{ Management of oil palm plantation understorey } \\
\cline { 2 - 7 } & \multicolumn{2}{|c|}{ Herbicides } & $\begin{array}{c}\text { Without herbicides and } \\
\text { beef cattle grazing }\end{array}$ & \multicolumn{2}{c|}{ Beef cattle garazing } \\
\cline { 2 - 7 } & Value & Criteria & Value & Criteria & Value & Criteria*) \\
\hline Water Content $(\%)$ & 21.89 & - & 14.85 & - & 19.36 & - \\
\hline Texture & Clay & & Loamy & & Dusty Clay & \\
\hline \multirow{2}{*}{$\mathrm{pH}\left(\mathrm{H}_{2} \mathrm{O}\right)$} & 5.8 & $\begin{array}{c}\text { Slightly } \\
\text { Acid }\end{array}$ & 5.5 & Slightly Acid & 5.5 & $\begin{array}{c}\text { Slightly } \\
\text { Acid }\end{array}$ \\
\hline $\mathrm{C}$-organic $(\%)$ & 4.9 & High & 3.7 & High & 10.3 & Very High \\
\hline $\mathrm{N}(\%)$ & 0.03 & Very Low & 0.03 & Very Low & 0.63 & High \\
\hline $\mathrm{P}-\mathrm{Bray}(\mathrm{ppm})$ & 0.51 & Very Low & 0.50 & Very Low & 0.58 & Very Low \\
\hline $\mathrm{K}-\mathrm{dd}(\mathrm{cmol} \mathrm{kg})$ & 0.10 & Low & 0.15 & Low & 0.15 & Low \\
\hline $\mathrm{KTK}\left(\mathrm{mol}(+) / \mathrm{kg}^{-1}\right)$ & 23.49 & Moderate & 16.57 & Moderate & 22.74 & Moderate \\
\hline $\left.\mathrm{Na}-\mathrm{dd}(\mathrm{cmol} \mathrm{kg})^{-1}\right)$ & 0.16 & Low & 0.18 & Low & 0.19 & Low \\
\hline $\left.\mathrm{Ca}-\mathrm{dd}(\mathrm{cmol} \mathrm{kg})^{-1}\right)$ & 3.49 & Low & 2.00 & Low & 2.12 & Low \\
\hline $\mathrm{Mg}-\mathrm{dd}\left(\mathrm{cmol} \mathrm{kg}{ }^{-1}\right)$ & 0.16 & Low & 0.04 & Low & 0.07 & Low \\
\hline $\mathrm{Al} l^{3+}$ & 0.06 & & 3.40 & & 3.80 & \\
\hline $\mathrm{K}(\mathrm{HCl} 25 \%)$ & 0.10 & Very Low & 0.15 & Very Low & 0.15 & Very Low \\
\hline $\mathrm{P}(\mathrm{HCl} 25 \%)$ & 0.51 & Very Low & 0.50 & Very Low & 0.58 & Very Low \\
\hline
\end{tabular}

*) Source [7] 
The level of acidity $(\mathrm{pH})$ of the soil in the three managements above ranged from 5.5 to 5.8 and was classified as slightly acidic, there was no difference in the three treatments. This situation is still suitable for oil palm plantations. According to the opinion [10], oil palm plants can grow at a $\mathrm{pH}$ of $4-6.5$ with an optimum $\mathrm{pH}$ of $5-5.5$. Furthermore, observations of organic $\mathrm{C}$, including high to very high. Cattle grazing gave the highest yield of $10.3 \%$ compared to management without herbicides (3.7\%) and herbicides (4.9\%). The increase of organic $\mathrm{C}$ comes from plant litter and cow feces and urine. Fertilizers derived from cow feces and urine contain many decomposing microorganisms that are useful for increasing nutrients and microorganisms.

Management of oil palm plantation with cattle grazing indicated that the nitrogen content was high, while the herbicide and without herbicide $\mathrm{N}$ content was very low, ranging from $0.03 \%$. The $\mathrm{N}$ content in cattle grazing is high due to the addition of manure. This is supported by [11], that the manure applied to oil palm plantations on the soil significantly affects the availability of the total $\mathrm{N}$-content of the soil.

Another nutrient status in the three treatments, such as P's availability is deficient, and the availability of bases ( $\mathrm{Na}, \mathrm{Mg}, \mathrm{K}$ and $\mathrm{Ca}$ ) is low, while the CEC is moderate. In general, the fertility rate in the proper management of oil palm with cattle grazing is more fertile when compared to herbicides and non-herbicides. This is due to cattle grazing management inadvertently adding organic matter to the soil through the manure produced by grazing cattle.

\subsection{Identification of understorey species in oil palm plantation}

Types of the understorey in oil palm plantation in Lubuk Banyau Village are very diverse, influenced by weed management techniques. Based on the identification results in the three plantations in the research location, it was found that the total number of understorey species in oil palm plantation was 34 species classified into 28 genera and 17 families (Table 3).

From the three managements of oil palm plantation, the most types were obtained in the management without herbicides, meaning that the oil palm plantation were left unattended without any management, while in herbicide management and cattle grazing, it would affect the underlying plants. [12] The vegetation that grows around the plantations varies widely, depending on the age of the oil palm plantations. Furthermore, [4] the control of understorey on plantation land using herbicides will affect the success of understorey.

The undergrowth in oil palm plantation can be used as cattle feed $[13,14,15,16]$. Although besides being used as animal feed, it also reduces the cost of weeding or eradicating weeds [4], the cost of weed eradication can be saved in the range of 30-60\%. Furthermore, other benefits of the undergrowth of oil palm can also be used for human purposes, especially for herbal medicines such as melastoma melabatricum [17]. 
Tabel 3. The results of the identification of plant species based on management with herbicides, without herbicides and Bali cattle grazing

\begin{tabular}{|c|c|c|c|c|c|}
\hline \multirow[b]{2}{*}{ Family } & \multirow[b]{2}{*}{ Genus } & \multirow[b]{2}{*}{ Spesies } & \multicolumn{3}{|c|}{$\begin{array}{c}\text { Management of oil palm plantation } \\
\text { understorey }\end{array}$} \\
\hline & & & $\begin{array}{l}\text { Herbi- } \\
\text { cides }\end{array}$ & $\begin{array}{l}\text { Without } \\
\text { Herbicides } \\
\text { and beef } \\
\text { cattle grazing }\end{array}$ & $\begin{array}{c}\text { Beef } \\
\text { cattle } \\
\text { grazing }\end{array}$ \\
\hline \multirow[t]{5}{*}{ 1. Poaceae } & 1. Acroceras & 1. Acroceras mипroamum & & $\sqrt{ }$ & $\sqrt{ }$ \\
\hline & 2. Axonopus & 2. Axonopus compressus & $\sqrt{ }$ & $\sqrt{ }$ & $\sqrt{ }$ \\
\hline & 3. Centotheca & 3. Centotheca lappacea & $\sqrt{ }$ & & \\
\hline & 4. Ischaemum & 4. Ischaemuт muticum & $\sqrt{ }$ & $\sqrt{ }$ & $\sqrt{ }$ \\
\hline & 5. Paspalum & 5. Paspalum conjugatum & & & $\sqrt{ }$ \\
\hline \multirow[t]{3}{*}{ 2. Asteraceae } & 6. Ageratum & 6. Ageratum conyzoides & & $\sqrt{ }$ & \\
\hline & 7. Praxelis & 7. Praxelis clematidea & & $\sqrt{ }$ & \\
\hline & 8. Synedrella & 8. Synedrella nudiflora & & $\sqrt{ }$ & \\
\hline \multirow{4}{*}{ 3. Rubiaceae } & 9. Mitracarpus & 9. Mitracarpus hirtus & & $\sqrt{ }$ & \\
\hline & 10. Oldenlandia & $\begin{array}{l}\text { 10. Oldenlandia } \\
\text { auricularia }\end{array}$ & $\sqrt{ }$ & & \\
\hline & \multirow[t]{2}{*}{ 11. Spermacoce } & 11. Spermacoce alata & & $\sqrt{ }$ & $\sqrt{ }$ \\
\hline & & $\begin{array}{l}\text { 12. Spermacoce } \\
\text { articularis }\end{array}$ & & & \\
\hline \multirow[t]{3}{*}{ 4. Cyperaceae } & \multirow[t]{2}{*}{ 12. Суретиs } & 13. Cyperus rotundus & & $\sqrt{ }$ & $\sqrt{ }$ \\
\hline & & 14 Cyperus shacelatus & & $\sqrt{ }$ & \\
\hline & 13. Scleria & 15. Scleria bancana & $\sqrt{ }$ & & \\
\hline 5. Lamiaceae & 14. Hyptis & 16. Hyptis capitata & & $\sqrt{ }$ & \\
\hline \multirow[t]{2}{*}{ 6. Linderniaceae } & 15. Lindernia & 17. Lindernia dubia & & $\sqrt{ }$ & $\sqrt{ }$ \\
\hline & 16.Legazpia & $\begin{array}{l}\text { 18. Legazpia } \\
\text { polygonoides }\end{array}$ & & & $\sqrt{ }$ \\
\hline 7. Schizaeaceae & 17. Lygodium & 19. Lygodium flexиosum & $\sqrt{ }$ & $\sqrt{ }$ & \\
\hline \multirow[t]{2}{*}{ 8. Melastomataceae } & 18. Clidemia & 20. Clidemia hirta & $\sqrt{ }$ & $\sqrt{ }$ & \\
\hline & 19. Melastoma & $\begin{array}{l}\text { 21. Melastoma } \\
\text { malabathricum }\end{array}$ & $\sqrt{ }$ & $\sqrt{ }$ & \\
\hline 9. Phyllanthaceae & 20. Phyllanthus & 22. Phyllanthus debilis & & $\sqrt{ }$ & \\
\hline 10. Acanthaceae & 21. Asystasia & 23. Asystasia gangetica & $\sqrt{ }$ & $\sqrt{ }$ & \\
\hline 11. Fabaceae & 22. Desmodium & $\begin{array}{l}\text { 24. Desmodium } \\
\text { heterophyllum }\end{array}$ & & $\sqrt{ }$ & \\
\hline 12. Gleicheniaceae & 23. Dicranopteris & 25. Dicranopteris linearis & $\sqrt{ }$ & $\sqrt{ }$ & \\
\hline \multirow[t]{2}{*}{ 13. Onagraceae } & 24. Ludwigia & 26. Ludwigia hyssopifolia & & & $\sqrt{ }$ \\
\hline & & 27. Spermacoce articularis & & & $\sqrt{ }$ \\
\hline 14. Lycopodiaceae & 25. Lycopodiella & 27. Lycopodiella cernua & & $\sqrt{ }$ & \\
\hline 15. Commelinaceae & 26. Murdannia & 28. Murdannia spirata & & & $\sqrt{ }$ \\
\hline 16. Verbenaceae & 27. Stachytarpheta & $\begin{array}{l}\text { 29. Stachytarpheta } \\
\text { jamaicensis }\end{array}$ & & $\sqrt{ }$ & \\
\hline \multirow[t]{6}{*}{ 17. Tectariaceae } & \multirow[t]{6}{*}{ 28. Tectaria } & 30. Tectaria crenata & $\sqrt{ }$ & $\sqrt{ }$ & \\
\hline & & 31. Anonim & $\sqrt{ }$ & & \\
\hline & & 32. Anonim & $\sqrt{ }$ & & \\
\hline & & 33. Anonim & $\sqrt{ }$ & & \\
\hline & & 34. Anonim & $\sqrt{ }$ & & \\
\hline & & & 15 & 22 & 11 \\
\hline
\end{tabular}

\subsection{Palm oil production in understorey palm oil plantation management}

The productivity of palm oil smallholders is still low, as can be seen from the yield of palm oil harvested in the form of Fresh Fruit Bunches (FFB). Harvesting is done two times a month. The management of oil palm plantation with cattle rearing gives better results than herbicide and non-herbicide management and is presented in Table 4. 
Table 4. Production of oil palm plantations ( $\mathrm{kg} / \mathrm{ha})$

\begin{tabular}{|l|c|c|c|c|}
\hline \multirow{2}{*}{ Description } & \multicolumn{2}{|c|}{ Management of oil palm plantation understorey } & \multirow{2}{*}{ PORC $\left.{ }^{*}\right)$} \\
\cline { 2 - 4 } & Herbicide & $\begin{array}{c}\text { Without } \\
\text { Herbicide }\end{array}$ & $\begin{array}{c}\text { Bali Cattle } \\
\text { Herding }\end{array}$ & \\
\hline Productivity & 20.400 & 18.240 & 27.360 & S1 $=32.000$ \\
TBS (Kg/ha) & & & & S2 $=30.000$ \\
& & & & S3 $=28.500$ \\
\hline
\end{tabular}

Note $^{*}$ TBS (Fresh Fruit Bunch), PORC $=$ Palm Oil Research Center, S1,2,3 = Sales 1,2,3

Based on Table 4, it was found that the management of oil palm plantation, with Bali cattle grazing, gave the highest yield $(27,360 \mathrm{~kg} / \mathrm{ha} / \mathrm{year})$ compared to management using herbicides $(20,400 \mathrm{~kg} / \mathrm{ha} /$ year) and without herbicides $(18,240 \mathrm{~kg} / \mathrm{ha} /$ year $)$. The oil palm productivity produced in the three oil palm plantation is still low compared to the Oil Palm Research Center [16], 32,000 kg/ha/year at the age of 15 years. Oil palm productivity depends on the environment, technical culture and the treatment given [18]. The results obtained by farmers from raising Bali cattle are higher because livestock consume plants under oil palm. In addition, the yield of palm FFB is also higher because cow faeces and urine are fertilizers that can fertilize oil palm growth. [19], cattle grazing with oil palm acts as a compost producer, while feed comes from the biomass found in the plantation area. According to [20], solid feces from cows contains $\mathrm{P}$, while cow urine contains $\mathrm{N}$ and K. Furthermore, [21] stated that cow urine without any addition contains $\mathrm{N}, \mathrm{P}$ and $\mathrm{K}$ respectively $5.80 \%, 3.80 \%$ and 0 , $45 \%$. Achmad and Aisyah $[22,23]$ mentioned that cow urine contains certain hormones that can stimulate plant development and contains more $\mathrm{N}$ and $\mathrm{K}$. Biourin can provide an increase in plant yields that is almost the same as plant fertilizers (BPT) [24].

\section{Conclusion}

Weed management by beef cattle grazing under oil palm plantation positively impacts soil fertility with the high organic carbon and nitrogen parameter value. The other positive impact of using this management will increase oil palm productivity compared to other oil palm plantation understorey management and is closer to marginally suitable (S3).

Acknowledgments : The authors acknowledged the head office of Assessment Institute of Agriculture Technology of Bengkulu and all member of research team.

\section{References}

1. BPS. Luas perkebunan kelapa sawit. Badan Pusat Statistik (2020).

2. J.F.McCarthy, P.Gillespie and Z.Zen, World Dev. (40) 555-69 (2012)

3. BPS Provinsi Bengkulu 2020 Provinsi Bengkulu Dalam Angka ed B P Bengkulu (Bengkulu (Id): Badan Pusat Statistik Provinsi Bengkulu) (2020)

4. J.Firison, Wiryono, dan B. Brata. J. Penelitian Pengelolaan Sumberdaya Alam dan Lingkungan (2019).

5. M.A. Ayob and M.A. Kabul. Cattle Integration in Oil Palm Plantation through Systematic Management. The 1st International Seminar on Animal Industry 2009 Faculty of Animal Science, Bogor Agricultural University (2009).

6. N.B. Costa, T.C. Baldissera, and C.E. Pinto, Public policies for low carbon emission agriculture foster beef cattle production in southern Brazil. Land Use Policy 80, 1: 269273 (2019)

7. BPS. Kabupaten Bengkulu Utara dalam angka (2015). 
8. L. Y. Sonbait, J. Ilmu Peternakan 4, 1: 19-25 (2009).

9. Badan Penelitian dan Pengembangan Pertanian. Petunjuk Teknis Analisa Kimia Tanah, Tanaman, Air dan Pupuk (2012).

10. Oksana, M. Irfan, dan M.U. Huda. J. Agroteknologi 3, 1: 29-34. (2012).

11. Sunarko. Budidaya Kelapa Sawit Di Barbagai Jenis Lahan. PT Agromedia Pustaka. Jakarta Selatan (2014).

12. B. Sudaryanto, Peluang penggunaan daun kelapa sawit sebagai pakan ternak ruminansia. Prosiding Seminar Nasional Peternakan dan Veteriner. Jilid I. Bogor, 1819 November 1997. Pusat Penelitian dan Pengembangan Peternakan, Bogor. 428-433 (1997).

13. B.N. Utomo, dan E. Widjaja. J. Litbang. Pert 31, 4: 153-161 (2012).

14. V.W. Hanifah, T. Rahmawati, dan K. Diwyanto. Menelisik Empat Tahun Kegiatan pendampingan Balai Pengkajian Teknologi Pertanian Terhadap Program swasembada Daging Sapi dan Kerbau dalam Model Pengembangan Integrasi Tanaman - Sapi Berbasis Inovasi. Editor : B. Damardjati, R. Tahir. IAARD Press, Jakarta. 87-118 (2013).

15. S.Suharti, Pemanfaatan Tumbuhan Bawah di Zona Pemanfaatan Taman Nasional Gunung Merapi oleh Masyarakat Sekitar Hutan. Pro. Semnas .Masyarakat Biodiv Indon 1, 6: 1411-1415 (2015).

16. N.D. Purwantari, D. Usmadi, dan J.T. Hadiah. J. Ilmu Kehutanan 12, 61-73 (2018).

17. J.Firison, A. Ishak, T. Hidayat. J. Agritepa 5, 1 (2018), ISSN 2407-1315.

18. Pusat Penelitian Kelapa Sawit (PPKS). Standar Produksi Kelapa Sawit berdasarkan Kelas Kesesuaian Lahan. (2015).

19. Suryana dan M. Yasin, J. Litbang Pert. 34, 1 Maret 2015: 9-18 (2015).

20. I. S. Roidah, J. Universitas Tulungagung Bonorowo 1, 30- 42 (2013).

21. F. Indriani, E.Sutrisno dan S.Sumiyati. J. Pupuk Organik Cair 2, 1-8 (2013).

22. Ahmad S.N. dan A. N. Sariffudin. J. Peternakan Nusantara 5, 1 (2019).

23. S. Aisyah, N.Sunarlim dan B.Solfan. J. Agriteknologi 2, 1-5 (2011).

24. S.N. Perdana, W.S.Y.Dwi dan M.Santoso. J. Produksi Tanaman 3, 457-463. (2015). 